\title{
The German Archeological Missions in Egypt during the Era of Khedive Ismail 1863 - 1879
}

\author{
Enas Fares Yehia Ali \\ Faculty of Tourism and Hotels-Minia University
}

\begin{abstract}
Although Egyptology was not among the interests of the Egyptian rulers, Khedive Ismail paid a lot of attention to it, encouraging archeological excavations in Egypt. During his era, Egypt witnessed a series of excavations and archeological studies conducted by Europeans. The Germans contributed largely to the discovery of Ancient Egypt. Their contributions varied from formal missions to individuals' interest. The names of Lepsius, Brugsch and Dumichen decorated the façade of the Egyptian museum, and this is a reflection of their role in Egyptology. Brugsch was the leading figure in German Egyptology during this era.
\end{abstract}

\section{Key words: Germany, Khedive Ismail, Egyptology}

\section{Introduction}

Accounts and drawings of travelers such as Pococke and Norden attracted European attention to the beauty of Egypt, followed by Bonaparte's campaign, the famous publications of Vivant Denon in 1802, and the Description de l'Egypte from 1809 to $1826^{1}$. The scientific investigation of the Egyptian antiquities by western scholars began after the discovery of the Rosetta stone during the French campaign to Egypt in $1799^{2}$. After this, a large number of Europeans visited Egypt to examine the Egyptian monuments.

Foreigners were very active in Egypt during Mohamed Ali's era, both economically and culturally, as he asked them for help with the building of modern Egypt, and also allowed them to own agricultural lands ${ }^{3}$.However, the first half of the nineteenth century differed from the second half in terms of the reasons for the foreign presence in Egypt: in the first half the reasons were economic and in the second half most of the visitors were interested in studying and collecting monuments.

The monuments were of no value to the rulers of Egypt, who simply used them as a tool to gain what they wanted from the Europeans. Archeology was used as a subject of interest, and became a tool in the competition between France, Great Britain and Germany. Muhammad Ali's first attempt to build a museum was important because it put restraints upon the peasants and the Europeans too. These restraints prohibited individual discoveries. It was ordered that any monuments collected by peasants had to be sent to Cairo to be kept in the Al Alsun School in Al Azbakia to be supervised by Refaa Al Tahtawi. Those monuments remained in Al Azbakia until October 1849. Mohammed Ali's successors encouraged these excavations as well. Although Egypt decided to regulate the visits of the Europeans in an 1857 decree, this decree did not prevent their presence in Egypt ${ }^{4}$.

Khedive Ismail, despite the financial, political and socioeconomic crisis that occurred at the end of his rule, and led to the British occupation,he was eager to represent himself as an enlightened European ruler. Ismail achieved great things for Egypt, erecting many palaces, building railroads, digging irrigation canals, and building factories, and he attempted to make Cairo as beautiful as Paris.

He also paid great attention to cultural institutions. He constructed the khedival library, the khedival geographical society, the Opera house, and a theater, and set up the first school of Egyptology, madrast elsan elmasry elqadeem. Worthy of mention here is that two institutions were concerned with Egyptology: the Institute Egyptian that was founded in Alexandria in 1859, and the khedival geographical society established in 1875 .

On the archeological front, Ismail issued a series of laws on 21 April1863 addressed to the inspectors of antiquities. They stipulated that Mariette Pasha's demands for help in his excavations in Upper Egypt must be met. It was specified that workers on site should be paid, and the destruction of monuments, or the use of 
stones from monuments for erecting government or private buildings, was forbidden ${ }^{5}$.Also, it was stipulated that any antiquities chanced by the Egyptians should automatically become the property of the Antiquities Service. The governor in Luxor was ordered to provide all necessary facilities to Mariette Pasha and his team.

\section{German-Egyptian Relations during the Era of Khedive Ismail}

Egypt witnessed the immigration of a large number of foreigners in the nineteenth century, especially during the era of Khedive Ismail, when the number of foreigners reached 100,000, consisting mostly of Germans stationed in Cairo and Alexandria ${ }^{6}$.

The Germans refused to engage colonial expansion at first, as Bismarck was not in need of it ${ }^{7}$, but after the industrial revolution Germany searched for new markets for their products, especially in Africa. Besides this, the emergence of the socialist movement under Karl Marx, and the Berlin conference of 1884-1885, affected German policy greatly, with the occupation of African countries advised ${ }^{9}$.

Of relevance here is that the German army was one of the strongest in the world during the second half of the nineteenth century, numbering 427,000 in 1880 , and as many as a million during emergency status ${ }^{10}$. Actually, Germany headed Europe between 1870 and 1914, as the French Revolution left its print on most European countries but did not affect Germany ${ }^{11}$.

The Prussian victory over France in 1870 affected the policy of Khedive Ismail significantly, and he asked for the help of German experts, instead of French, in organizing Egypt's army ${ }^{12}$. Bismarck desired a European balance to substantiate the German influence and asked Great Britain to occupy Egypt and France Tunisia ${ }^{13}$.Germany had no objection to the British occupation of Egypt under Bismarck's policy of dividing the Ottoman countries between the European countries ${ }^{14}$.

\section{Economic Relations}

In spite of the economic treaty between the Ottoman Empire and Prussia in 1840, which had many advantages for Prussia, little was mentioned about economic activity between Egypt and Prussia. This was due to unrest in Prussia and German immigration prior to the unification of Germany, and the resulting lack of political unity ${ }^{15}$.

The German interest in Egypt started at the end of the eighteenth century and increased at the beginning of the nineteenth century. The purpose of this interrest in Egypt was trade. In spite of the small number of Germans in Egypt (just 1,100 in 1871), they were among the most active communities, working as barbers, engineers and booksellers ${ }^{16}$.

The Germans also practiced many other types of trade in Egypt, such as the cigarette paper trade, and the cardboard and cotton industries. They obtained land in Ismailia to form a colony for the German community ${ }^{17}$. After the opening of the Suez Canal, Germany started to realize the importance of Egypt. This led the German chancellor Bismarck to send a memorandum to the government, emphasizing the importance of the canal to the Germans ${ }^{18}$.

Germany was involved in both Egyptian imports and exports. In the case of the former, this was possibly because the German products were cheap and suitable for the Egyptian market. During Khedive Ismail's era, German imports increased, reaching a value of 6,159 Egyptian pounds in $1865^{19}$.The Egyptian exports to Germany were mainly cotton, which had long been a staple, as Egyptian cotton benefited from the scarcity in Europe following the American Civil War, and the entire world's subsequent concentration on Egyptian $\operatorname{cotton}^{20}$.

\section{Cultural Relations}

Khedive Ismail constructed many scientific institutions in Egypt; among these institutions is the Geographical Assembly that was established in 1875 . Worthy of note here is that its first director was the German scientist Dr. G.Schweinfurth ${ }^{21}$. 
The Egyptian Library (kotob Khanah) also had a German director, Ludwig Stern, and the German government donated a number of books to $\mathrm{it}^{22}$, beside participating in exploratory missions to the Sudan. There were also many scientific missions executed by Germany during the era of Khedive Ismail ${ }^{23}$.

\section{German Tourists in Egypt}

It is also worth mentioning here that a large number of Germans came to Egypt for tourism reasons. Austrian steamers played an important role in transporting them, about 140 Germans traveled to Egypt on these ships $^{24}$. Two of the most important German tourists to Egypt were Prince Friedrich Wilhelm, the crown prince of Germany, and the Prussian Prince Albert who traveled from Alexandria to Aswan ${ }^{25}$.

Due to the increasing number of German tourists in Egypt, beside being a kind of German investment in the country, many hotels were built, such as the Savoy Hotel in 1888. The growth of the German community in Egypt led them to found their own hospital in Alexandria, which served both Germans and Egyptians ${ }^{26}$.

Although the excavations in Egypt were concentrated in the hands of the Frenchman Mariette ${ }^{27}$, the Germans also started excavations alongside the French and the Italians.

\section{The German Interest in Egyptology}

Egypt was accessible to European expeditions, here the French and the Italians were the pioneers, but Prussia was determined to make its impact on these discoveries. Germany had not yet been unified ${ }^{28}$ when archeology developed from individual interest to classical culture; during these early days, working in the archeological field required private assets and support.

The German interest in Egyptology started during the nineteenth century when the Prussian King Philiham IV had been affected by the writings of the famous traveler Happold, who advised him to send an archeological mission to Egypt $^{29}$.The German excavations in Egypt were initiated by Heinrich von Minutoli $^{30}$, whose collection formed the basis of the Berlin Museum. An organized scientific mission to Egypt was planned. The Sciences Academy appointed Hemprich and Ehrenberg to lead the mission, and King Friedrich Wilhelm appointed Liman as the architectural expert of the mission.In spite of the failure of this mission, Minutoli stayed for about a month in Alexandria, making social contacts [with Mohammed Ali and with European diplomats such as Drovetti and Salt.

He bought a collection of ancient vases, in November he went to Siwa Oasis, and after his return to Cairo he rented a ship to make a trip to Upper Egypt. On this trip he visited Minya, Bani Hasan, Hermopolis, Malawh, Asyut, Gau el Kebir, Akhmim, and Abydos ${ }^{31}$.

He visited the monuments in Luxor, Esna, Komombo and Silsile; he bought three large archeological collections including papyri, coffins, objects of daily life, and musical instruments ${ }^{32}$. With the help of the Prussian consul of Brandenburg, these pieces were loaded onto a Danish ship to be transported to Hamburg. However, the ship sank, and despite many German attempts, none of the pieces were recovered.

He spent ten months in Egypt in total, producing many descriptions of ancient monuments, and conducting excavations in some parts of the Step Pyramid at Saqqara, alongside his role as a collector of monuments that would form the nucleus of the Berlin Museum. His mission affected the Prussian king greatly, and led him to sponsor Lepsius's mission to Egypt.

Individuals as well as institutions are always affected by both political and social conditions, and despite such impacts on archeological research in Germany, the individual interest in Egyptology increased, accompanied by adventure, until the last quarter of the nineteenth century which witnessed the foundation of the German Empire in 1871. German Egyptology started with archeological missions instigated by the king.

\section{Germany's Formal Archeological Missions to Egypt}

1- Lepsius's mission

2- Brugsch's mission

3- Dumichen's mission 
Although the archeological missions of both Lepsius and Brugsch had began before the reign of Khedive Ismail, their role and presence in Egypt continued until the end of his reign.

After that, Egyptology spread across Germany, for example to Gottingen in 1868 under Heinrich Brugsch, to Strasbourg in 1872 under Johannes Dumichen, and to Heidelberg in 1872 under August Eisenlohr, all of which was started by Lepsius.

\section{Lepsius's Mission}

In 1842, Fredrick Wilhelm IV King of Prussia funded the first German archeological mission to Egypt and the $\operatorname{Sudan}^{33}$.In fact, its purpose was not to further science and art, but to collect pieces for the Berlin Museum.

Lepsius headed this mission to Egypt to make a survey of the Egyptian monuments ${ }^{34}$. this mission exceeded its purpose and instigated a series of excavations in Egypt. He succeeded in collecting about 15,000 archeological pieces that formed the nucleus of the Berlin Museum. Lepsius's writings are considered as an important reference for Germans in discovering Ancient Egypt. Lepsius went on to train the next generation of German Egyptologists.

The mission was proposed by Johann Eichhorn, who was then the Prussia's Minister of Instruction, and was endorsed by the scientists Alexander von Humboldt and Robert Wilhelm Bunsen ${ }^{35}$. Included in his team were an artist named Joseph Bonomi and an English architect named James Wild, together with surveyors, other artists, draftsmen and a plaster molder ${ }^{36}$. Altogether, this was the best-equipped and best-qualified compared to any scholarly group since the French Egyptologists.

Lepsius must be considered one of the founding fathers of Egyptology and a giant among the earliest archaeologists. During the days before formal graduate programs in Egyptology, he spent years studying Champollion's Grammar in order to learn hieroglyphs, and then spent another four years visiting all of the major European collections of Egyptian antiquities in England, Holland and Italy, in order to educate himself in his chosen discipline.

The mission gathered in September of 1842. It reached Alexandria on 23 September 1842, and stayed there for about 14 days, discovering its monuments and visiting Pompey's pillar. On 2 October the mission visited Tanis, followed by Rosetta, before reaching Cairo ${ }^{37}$.

On 15 October it reached the pyramids. It was Lepsius's choice to reach the pyramids on this day, as it was the birthday of the Prussian king and he wanted to celebrate it at the Pyramids. As a way of commemorating the visit, he wrote the name of the king on the greatest pyramid, Cheops, and hung the Prussian flag on $\mathrm{it}^{38}$.

In May of 1843, the expedition settled in Fayoum near the remains of the Labyrinth (the Pyramid of Amenemhat III). It remained there for several months, carrying out excavations and, in the process, making the first detailed plans of that monument. Lepsius was the first Egyptologist to make stratified section drawings of excavations there ${ }^{39}$.

From there, the group traveled through Middle Egypt with stops at a number of sites such as Beni Hasan and Bersheh as it made its way up the River Nile. On the return journey downriver, it made a prolonged visit to Thebes, camped for four months at Qurnah on the West Bank to investigate the tombs and temples there, and then spent another three months on the eastern bank at the temples of Karnak. After leaving Thebes, the group made lengthy stops at the principal antiquity sites on its way back northward. Finally, leaving Egypt, the group returned to Europe, arriving in January $1846^{40}$.

It is important to note that Lepsius' first mission not only contributed to our knowledge of Egyptian monuments, the Egyptian language and mythology, but also to the geography of this region. With a carefully chosen team of specialists, Lepsius was able to take more time and care over his investigation and recording than had anyone before him. The expedition was instrumental in adding depth and detail to the understanding of Egyptian antiquities. 
For his work, Lepsius was rewarded in 1846with a professorship at the Berlin University, and in 1865 with the post of Keeper of the Egyptian Antiquities Department at the Berlin Museum ${ }^{41}$.

\section{Lepsius and the Discovery of the Canopus Decree}

In 1866, Lepsius returned to Egypt to explore the Eastern Delta, where he discovered Tanis ${ }^{42}$. This time, he explored the Delta, which was and continues to be under-investigated, and the Suez region. At Tanis, he discovered the Canopus Decree ${ }^{43}$, a document written in Greek and Demotic which proved extremely useful to scholars because it could be compared with the Rosetta stone. The translation of this inscribed stone proved that the system of hieroglyphic translations pioneered and used by Champollion had been correct.

In1869, Lepsius visited Egypt for the last time in order to witness the inauguration of the Suez Canal.His work did more than anyone else's to put Germany, and particularly the Berlin Museum, on the map in the field of Egyptology. He is considered the founder of the "German school" of methodical research on the language, antiquities and archaeology of ancient Egypt.

After his return to Prussia, his findings were published in a monumental work called Denkmaler aus Aegypten und Aethiopien, a twelve-volume series of books, with five volumes of text and nearly 900 plates. Today, it remains a fundamental resource for Egyptologists on monuments in Egypt and Nubia. The plans, maps and drawings of tomb and temple walls are highly accurate and reliable.

Lepsius trained most of the next generation of German Egyptologists. He died in1884in Berlin but published many more works during his later years, and was also the editor of the leading German Egyptology journal, the Zeitschrift fur agyptische Sprache und Altertumskunde. For many years, this was considered to be the most important early periodical journal on Egyptian antiquities. He is also credited with providing the modern title, "The Book of the Dead", to the famous book of spells and he published one of the earliest studies of the cubit rods.

\section{Heinrich Brugsch's Mission}

Another key figure in the development of German Egyptology was Heinrich Brugsch, 1827-1894. He studied in Berlin and Paris ${ }^{44}$. Brugsch led the German Egyptological field after Lepsius, being seventeen years younger than him. He gained his doctorate from Berlin, worked with Lepsius in Saqqara, and was the founder of the first Egyptology journal, the aforementioned Zeitschrift fur AgyptischeSprache und alter Tumskunde in $1863^{45}$, being at that time the only journal in Berlin devoted to Egyptology.

He was sent to Egypt by the Prussian King in 1853, where he worked with the French Egyptologist Mariette Pasha $^{46}$. They worked in Memphis and Saqqara, and studied the tombs surrounding the pyramids. Brugsch used Lepsius's maps in order to gain entry to the tombs more quickly. He was the pioneer of the deciphering of Demotic.

Brugsch accepted Mariette's invitation to share in his discoveries in the Serapeum; they stayed there for eight months. The Prussian king supported his excavations in Egypt so much that, when Brugsch wrote to him telling that he was returning because his funds had run out, the king decided to send him a further 1500 talers so that he could stay in Egypt for another year ${ }^{47}$.

Brugsch held many diplomatic posts; Khedive Ismail elevated him to a bey ${ }^{48}$ in 1863 , and he was appointed as the Prussian consul in Egypt. He was appointed Professor of Egyptology at the University of Gottingen in 1867. His contribution to Egyptology is enormous, not for his discoveries but for his recognition and study of the Egyptian Hieroglyphs. His inscriptions and translations became the fundamental work on Egyptian astronomy ${ }^{49}$.

\section{Brugsch as a Director of the School of Egyptology}

In 1865 Ali Mubarak offered Brugsch a contract to lead the School of Egyptology for five years. He was given a very respectable salary, an official dwelling in the middle of a beautiful garden, and many amenities $^{50}$. 
The school was situated in the suburb of Bulak. He succeeded, with the help of German teachers and an Abyssinian lecturer, in teaching the students German, French and English, introducing them to hieroglyphs, and teaching them the elements of the auxiliary sciences ${ }^{51}$.

Brugsch knew the importance of field trips to his students and took them to the monuments of Upper Egypt. His ideas on the ancient Egyptian religion were similar to those of Refaa Al Tahtawi, in that he believed the titles of the ancient Egyptian gods proved that a single divine being underlay these epithets.

He found it difficult to teach the students the Ancient Egyptian religion, writing the following about the matter $^{52}$ :

"A particular difficulty for me was to initiate them into the mysteries that are inseparable from the Ancient Egyptian mythology. "There is no God but God" is, as is well known, the rallying cry of Islam, and any reminder of gods a sin against the Koran and the Prophet Mohammed. Ancient Egypt was swarming with divinities, old and young, even to childhood, male and female, who married, produced children, and led a common family life. How was I to make it clear to my students that their ancestors were in the most complete contradiction to them in religious matters, and how to bring the essential nature of each individual deity closer to their conception? How often had I to resort, even here, to a trick, which permitted me to speak to my students of a multitude of Egyptian divinities, but not to let their Islamic "La illah'il Allah" run into too much of a dilemma, and burden their faith. Since, as is known, the Arabs attribute to their Allah ninety-nine great qualities under as many names, I taught my students to recognize the designations of the ancient Egyptian gods as merely distinctive names of this one indivisible God, of whom even the pagan inscriptions say: "He is unique and alone, and there is no other God except him." Names of gods like Amon, that is, "the Hidden One," in Thebes, Ptah, that is "the Creator," in Memphis, among others, began to exert even a certain power of attraction on my students, and fundamentally my explanation and conception were not too far from the truth".

Thus, he was keen to teach the students honestly and include everything about Ancient Egypt.

It is worthy of mention here that the Frenchman Mariette began to worry that the Khedive might have a secret plan to appoint in his museum native officials familiar with hieroglyphic studies. He thus ordered the museum attendants not to permit any native to copy hieroglyphic inscriptions. Those concerned were simply pushed out of the temple.

The school was closed after his departure, but despite this two of its students were appointed to the Antiquities Service. They were Ahmed Nagib and Ahmed Kamal, and they contributed greatly to Egyptology $y^{53}$.

At the time of the opening of the Suez Canal on 17 November 1869, Prince Fredrick Wilhelm came to Egypt, not merely to attend the celebrations but also to visit Upper Egypt; Brugsch acted as the Austrian Emperor's guide.

\section{The Role of Brugsch in Discovering the Egyptian Gold Mines}

One day, Brugsch found himself at the breakfast table with Khedive Ismail, who asked him what hieroglyphic knowledge actually offered the world; he understood that Egyptian history, the teaching of the gods, and other theoretical things gave particular pleasure to individuals, but felt that in practice all such knowledge was about something dead ${ }^{54}$.

He wanted to know where buried gold treasures were to be found, and from where the ancient Egyptians had obtained all of their gold. Brugsch answered that he would only be able to satisfy his desire for knowledge of the former gold mines in Egypt if he sent an expedition that included real miners.

The Khedive seemed unbelieving, but gave his assent, and so Brugsch precisely described to him the goldbearing region of the so-called Valley of Hamamat, situated between the Nile and the Red Sea, from which, according to the hieroglyphic inscriptions from the earliest times, the Egyptians had extracted gold ${ }^{55}$. 
The Khedive seemed to place no faith at all in Brugsch's words, feeling that he could well have made a mistake in reading the text, and anyway doubting that such things would have been handed down by the Ancients. "In the meantime," he said, "deliver a short memorandum, which contains all the data, to General Stone, to serve as a director and leader of an expedition.

They discovered abandoned gold mines and found wells, still filled with sand, but which, once cleaned, revealed clear, drinkable water at the bottom. To the khedive the solution to the water problem was so important that he gave the order to have the town of Qussir at the opening of the gold valley near to the Red Sea coast fortified and armed with cannons, fearing a possible landing of English troops from India, now that the formerly waterless desert route had lost its inhospitality for a large army.

It was that, for which the Khedive had thanked Brugsch on his first reception. Even though later, under the pressure of affairs of state and of impending disaster, the idea of risking an attempt to work the mines escaped his mind, he nevertheless gained from this the conviction that the deciphering of the hieroglyphic texts rested on correct foundations.

\section{Brugsch and the International Exhibitions}

In 1873 a great world exposition was to take place in Vienna ${ }^{56}$, and Brugsch was responsible for organizing the Egyptian exhibit. In May of that year, the Egyptian Exhibit reached completion, and it was an outstanding success ${ }^{57}$. After his return to Cairo he was appointed as Commissioner General. Khedive Ismail received him with these words:"Welcome my dear bey; you have rendered me and my country a great service".

Barely two years had passed since the Vienna World Exposition, when, in Pennsylvania, the United States, the idea emerged to create, for the hundredth anniversary of its existence, a World Exposition in the Quaker city of Philadelphia ${ }^{58}$. An invitation was issued to the khedive of Egypt to contribute to it extensively, so as to make advances in the competition for the world industry.

Brugsch was once more entrusted with the task of organizing the Egyptian exhibition, although on a smaller scale. A credit of 10,000 pounds sterling was opened for him at a banking house in New York. The preparation and assembling of objects for the exhibition again claimed all his time and activity.

An incident occurred to make the exhibition impossible. As the crates stood ready to be transported to America, a bailiff of the International Tribunal presented a legal order, according to which the exhibition cases were to be sealed and confiscated. Lending emphasis to his order, in case of refusal, military help would be drawn upon. Brugsch asked for an hour's time for reflection and hurried to Khedive Ismail, who flew into a great rage, all the more so since the court had made the same attempt at his palace, again threatening the use of the military ${ }^{59}$.

A khedive stands above the International Tribunal. Fortunately they were prevailed upon, in consideration of the international interests of the exhibition, to deliver the cases to Brugsch, who did not delay the shipment for a moment longer. He made his way to Gottingen. Then, as he was on the point of leaving to take the early train to Bremen, he received a telegram, which he opened at once, so as to read its contents before departing. It was short and to the point: "The Khedive begs you to return to Cairo instantly." By the next express train, Brugsch set out in the direction of Trieste, in order to go back to Egypt on the Lloyd steamer that was due to leave $^{60}$, and the Egyptian Exhibit was held .

\section{Brugsch in the Second International Congress of Orientalists}

Brugsch represented Egypt at the Second International Congress of Orientalists in London. He started his speech with these words: "I was directed by an order from his highness the Khedive of Egypt Ismail to come to London in order to represent his country at the International Congress of Orientalists ${ }^{61 "}$. These words reflected the interest of Khedive Ismael in Egyptology. At this congress, Brugsch presented his research, entitled "Lake or Sea passed by the Israelites or their Exodus". 
Brugsch had realized that, without a full understanding of the ancient Egyptian inscriptions and texts, the various fields of his knowledge, above all, Egyptian history, floated in the air, and that empty names of kings and chronological tables could not claim to replace the substance of the traditions on stone and papyrus. In a word, he was eager to read, and not only guess, what the hieroglyphics concealed within themselves, and his desire to achieve that goal did not let him rest, day or night. Actually he was the one who had the antiquities a study.

\section{Johannes Dümichen's Mission}

A student of Lepsius and Brugsch, Dümichen was sent to Egypt by the Prussian government to discover the Nile valley in 1862 and again in $1868^{62}$. He studied the Ancient Egyptian language. In his first investigation of Egyptian monuments he concentrated on the inscriptions on these monuments, and he wrote many books describing the Ancient Egyptian epigraphical decorations.

Worthy of mention here is that Khedive Ismail encouraged him greatly in his investigations and provided him with many facilities, which led Dümichen to express his appreciation to the Khedive in most of his writings. In 1864, Dümichen copied a list of kings that Mariette's workmen had discovered at Abydos, and sent a copy to Lepsius, who published it without Mariette's consent.

Dümichen's second visit to Egypt was in 1869, when he accompanied the Prussian prince on his visit during the opening of the Suez Canal, and acted as his guide, describing the Egyptian monuments and the Ancient Egyptian culture. The king was so happy with his visit that he encouraged Dümichen to present more of his Egyptian archeological investigations in Prussia ${ }^{63}$.

His last trip to Egypt was in 1875, when he went to Thebes. There he investigated the private tombs inside the Theban necropolis, making accurate copies of all the inscriptions from inside the tombs.

The most important outcome of this trip was the rapidly following inscriptions art publications. They were surprising not only for their wealth and significance, but also for their great reliability. Dümichen's teacher Brugsch, who had just then completed his great dictionary of the Egyptian language, presented the new material before it was published ${ }^{64}$.

Dümichen was appointed Professor of Egyptology at the University of Strasbourg in 1872, where he taught successfully until his death on 7 February 1894.

The value of his work consists not only in the stores of material that he collected, but also in the success with which he dealt with many of the problems raised by the inscriptions. Among his works are the following ${ }^{65}$ :

- Bauurkunde des Tempels von Dendera

- Geographische Inschriften altägyptischer Denkmähler

- Altägyptische Kalenderinschriften

- Altägypt. Tempelinschriften

- Historische Inschriften altägypt. Denkmäler

- Die kalendarischen Opferfestlisten von Medinet-Habu

- Die Oasen der libyschen Wüste.

- Geschichte des alten Aegypten

- Der Grabpalast des Patuamenap in der thebanischen Nekropolis

Dümichen's great scientific importance lies in the fact that he helped in preparing text publications that revealed the history of the Ancient Egyptians. The deciphering of the coming of the Ptolemaic empire and hieroglyphic texts was achieved thanks to Dümichen who developed from the inscriptions in the temples of Edfu and Dendera an architectural history of those two great temples. The knowledge of the geography of Egypt and meteorology was considerably extended by Dümichen's work ${ }^{66}$.

Other German Egyptologists who contributed greatly to the discovery of Ancient Egypt during the era of Khedive Ismail, but without government funding for their excavations, included 
- August Eisenlohr

- George Ebers

\section{Émile Brugsch}

The brother of Heinrich Brugsch, Émile went to Egypt in 1870 to help his brother in the khedive's newly founded School of Egyptology, where he taught the German language. Although the school was closed in 1879, Émile stayed in Egypt, and became a friend of Mariette. In 1872, Mariette appointed him as an assistant conservator at the Boulak Museum ${ }^{67}$.He discovered the famous cache in El Dier El Bahary in Thebes. When word came that a cache of royal mummies had been found there, Émile took the first pictures of them. He was likewise responsible for many of the photographic plates illustrating other early volumes of the museum's catalogue. He was the first person to photograph the great Naos of the temple of Banebdjed ${ }^{68}$.

Émile Brugsch remained assistant conservator until he retired in January 1914, at the age of seventy-two. He then returned to Nice, where he died in 1930.

That Émile Brugsch decided to stay in Egypt even after the closure of the school to which he had gone from Berlin to work is a reflection of his admiration for Egyptology. He was the most famous European photographer of the Ancient Egyptian monuments.

\section{Eisenlohr, August}

Eisenlohr studied theology and then, after an interruption due to illness, chemistry in Heidelberg, where he received his doctorate in 1860 and founded a chemical factory. After1865, however, he devoted himself to Chinese and Egyptian language studies, and in 1869 he received his habilitation in Heidelberg for Egyptology ${ }^{69}$.

He made a study trip to Egypt in 1869, visiting Luxor where he was astonished by the greatness of the Ancient Egyptian monuments, including Dier El Bahry temple, Madient Habu temple, Abd ElQornah, and the tombs. Of note to this paper is that, during his journey, he used the writings of both Lepsius and Brugsch as a guide $^{70}$.

From Thebes, he went to study the temples of Philia, Kom Ombo, and El Kab.On his return journey he visited Sohag where he found and translated the Coptic Manuscripts, and Tel Elmarna in Minia, and he ended his tour of Egypt by visiting the Pyramids ${ }^{71}$.

He was the translator of the famous Harris papyrus which is considered one of the culturally most comprehensive, and historically most significant, sources of Ancient Egypt ${ }^{72}$.

In 1877, Eisenlohr effected the first publication and translation of the Hieratic text on the "Papyrus Rhind",the mathematical handbook of the Ancient Egyptians. The most complete of all surviving sources of Ancient Egyptian mathematics, it is a handbook of practical and theoretical exercises, including an introduction to fractions ${ }^{73}$.

The Rhind papyrus was discovered in 1858 by a young Scottish antiquarian Henry Rhind who, in Luxor, purchased a large papyrus said to have been found in the ruins of a small ancient building. After his death, the papyrus was acquired by the British Museum, but was broken into two parts, with several fragments. By chance the missing parts turned up in the deposits of the New York Historical Society ${ }^{74}$.Eisenlohr obtained the papyrus from Edwin Smith at Thebes, and supplied Brugsch with a copy of the Hieratic text. It should be mentioned that only one other mathematical papyrus has been found. It was discovered by Petri in Tanis and was translated by Eugene Revillout ${ }^{75}$.

Thus, Eisenholr contributed towards the discovery of the secrets of the Ancient Egyptian civilization, although he was assigned neither by his government nor by the Egyptian government to do so, simply being motivated by his desire to reveal the ancient secrets of the Egyptians. 


\section{George Ebers}

Ebers began his career by studying jurisprudence at Gottingen University, and then went on to Berlin to study oriental languages and archeology. In 1865, he began lecturing on his specialty, Egyptology and antiquities. Around this period of his life, Ebers' scholarly interest in Egyptology also led him to write rare, historically authentic romances ${ }^{76}$.

He made two scientific journeys to Egypt. After his first trip he wrote "Egypt and the Book of Moses" (1868). In 1870, the University of Leipzig asked him to fill the Egyptological Chair there.

During his second visit to Egypt, in 1873, he discovered and purchased the Ebers Medical Papyrus during excavations at Thebes. This papyrus is the oldest complete document describing medical remedies, and is now preserved in the University of Leipzig library ${ }^{77}$.

Like the Edwin Smith Papyrus, the Ebers Papyrus was purchased by Edwin Smith. Edwin Smith was an American living in Cairo, and has been described as a dealer of antiquities, an adventurer, and a money lender. It was purchased in Luxor. Whereas the source of the Edwin Smith Papyrus is known to be Mustafa Agha, it is unclear from whom Edwin Smith purchased the Ebers Papyrus. It has been claimed to have been discovered between the legs of a mummy in the Assassif district of the Theban necropolis ${ }^{78}$.

In 1873 , the papyrus was purchased by Georg Ebers, after whom it is named. He was shown the papyrus wrapped in old mummy bandages and apparently perfectly preserved. In 1875, Ebers published a twovolume, color photographic facsimile of the entire text. The papyrus contains extracts from different sources and dates back to the ninth year of the reign of Amonhotep I. It provides the most important account of Egyptian pathology ${ }^{79}$.

Early on, Ebers conceived the idea of popularizing Egyptian lore by means of historical romances. Eine ägyptische Königstochter was published in 1864 and found great success. His subsequent works of the same kind-Uarda (1877), Homo sum (1878), Die Schwestern (1880), Der Kaiser (1881), set in Egypt at the time of Hadrian, Serapis (1885), Die Nilbraut (1887), and Kleopatra (1894), were also well received, and did much to familiarize the public with the discoveries of the Egyptologists.

Ebers gained fame after the discovery of the medical papyrus; he contributed towards the understanding of Ancient Egypt through his writing and novels.

\section{Conclusion}

\section{Based on the above:}

- There appear to have been good relations between Germany and Egypt before and after Germany's unification.

- Khedive Ismail took great care of the German excavators in Egypt and provided them with all the facilities they needed to conduct their excavations.

- Brugsch was the leading figure of German Egyptology during this era, and he was the closest German Egyptologist to Khedive Ismail.

- The Germans contributed largely to teaching the Egyptians about the Ancient Egyptian civilization. This is apparent from Brugsch's role as a director of the first School of Egyptology in Egypt.

- Khedive Ismail used hieroglyphic inscriptions, with the aid of Heinrich Brugsch, to discover the gold mines that had been used by the Ancient Egyptians.

- Brugsch represented Egypt at international conferences and exhibitions, reflecting the khedive's trust in him. 
- The German Egyptologists of this era created the first journal of Egyptology (across the whole world).

- There were important German discoveries during this era, such as Lepsius's discovery of the Canopus Decree, and the Ebers Medical Papyrus.

- The Germans contributed largely to Egyptology during this era, with a mountain of publications in many fields, such as Ancient Egypt, Art, Architecture, Religion, Mythology, and Astronomy.

- The German Egyptologists were not all funded by the government. The government only funded the formal missions, while other Egyptologists acted out of curiosity at their own expense.

- This is not to say that Lepsius, along with other early Egyptologists, were not to blame for some needless destruction. All of the scholars were responsible for disfiguring monuments in Egypt, through the brutal removal of entire sections of decoration. Certainly, Lepsius was not the worst, but he did contribute to this destruction. The artifacts that he returned with after his first expedition included a dynamited column from the ill-fated tomb of Seti I, and sections of tiled wall from Djoser's Step Pyramid at Saqqara. Both were presents from Muhammad Ali in thanks for a dinner service presented to the Egyptian king by the Prussian king.

- At that time, it was the custom among the Europeans settled in the main cities of Egypt, chiefly in Alexandria and Cairo, to form Old Egyptian collections, which gained an increasing value over the year, and often contained, besides much that was worthless, some of the most precious objects of antiquity.

\section{Biblography}

${ }^{1}$ Paul Strakey and Janet Strarkey(ed.), Travelers in Egypt, an essay by Hussein M. Fahim, European Travelers in Egypt: The Representation of the Host Culture, (I.B. Tauris,New York, 1998), p.8

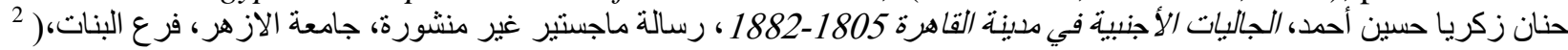

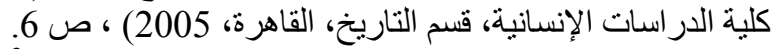

جون مارلو، النهب الاستعداري من الحملة الفرنسية 1798 البى الاحتلال البريطاني 1882 ، ت عبد العظيم رمضان، (الريئة الدصرية العامة 3

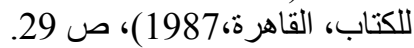

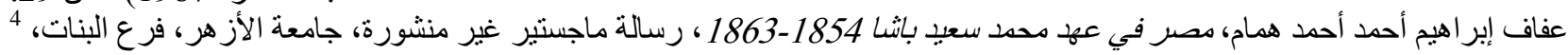

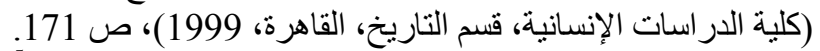

${ }^{5}$ Jill Kamil, Labib Habshi: the Life and Legacy of an Egyptologist, (A.U.C., Cairo, 2007), p.19

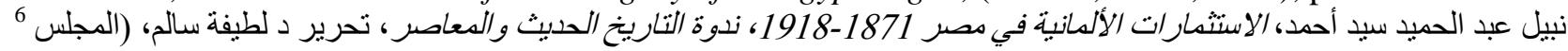

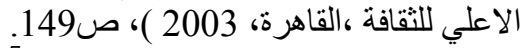

حسن صبحي، التنافس الاستعداري الاوروبي في الدغرب(1884-1904)، (دار المعارف، القاهرة، 1960)، ص 21. 7

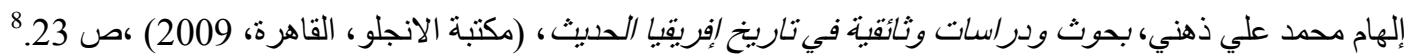

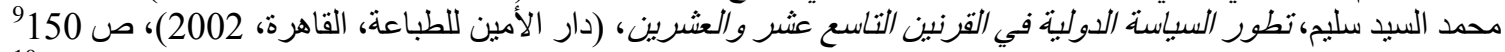

${ }^{10}$ Ibid., p. 150

${ }^{11}$ Louis L. Snyder, Basic History of Modern Germany, (Van Nostrand, New York, 1957), p.3.

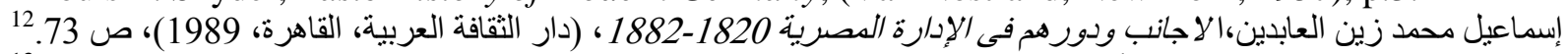

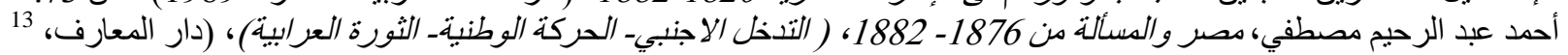

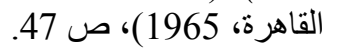

It is noteworthy that Great Britain was afraid of Bismarck's policy and did not trust his offer, but it seems that Bismarck was honest in his offer and wanted to create a new atmosphere between Great Britain and France.

عبد المنعم إبر اهيم الدسوقي الجميعي، الخديوي عباس الثاني والحزب الوطني 1892-1914،( دار الكتاب الجامعي، القاهرة، 1982)، ص 14 20

${ }^{15}$ This does not mean that there were no economic relations between Prussia and Egypt during the first half of the nineteenth century.A letter between Mohammed Ali and Artin Pasha, the Director of Commerce, orders him to give 2,600 Erdabs of wheat to Prussia. 


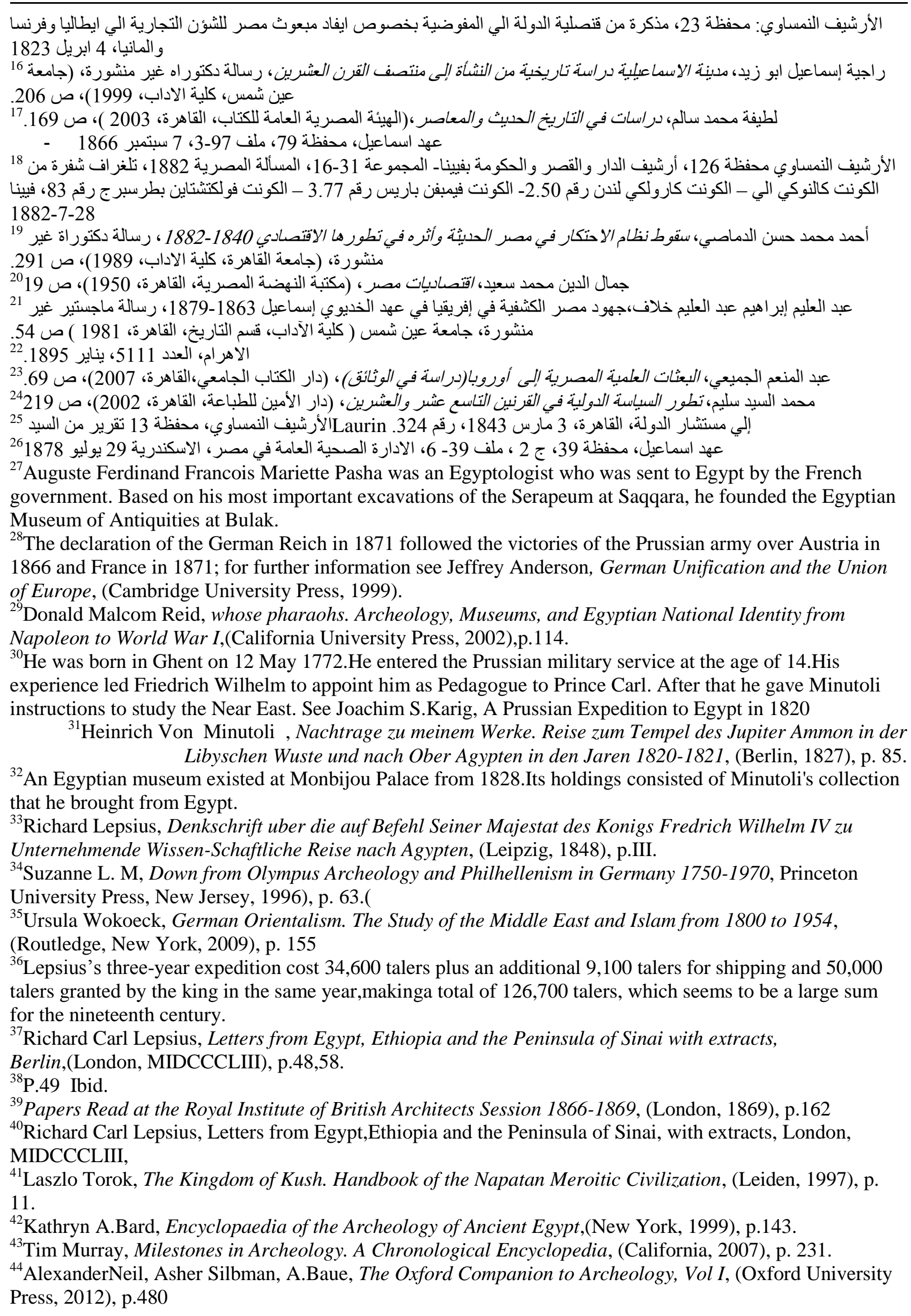


${ }^{45}$ Walter Ruegg(ed.), A History of the University in Europe, vol. III from 1800-1945,(Cambridge University Press, 2004), p.446.

${ }^{46}$ Heinrich Brugsch, Reiseberichte aus Aegypten, (Leipzig, 1855), p. II.

${ }^{47}$ A Letter from Alexander von Humboldt to Heinrich Brugsch 9 October 1853.

${ }^{48}$ Patrich Richard Carstens, The Encyclopedia of Egypt during the reign of the Mehemet Ali Dynasty 17981952, (Canada, 2014), p. 127

${ }^{49}$ New Scientist, 3 January 1980, Vol.85, No.188, p.40.

${ }^{50}$ Heinrich Brugsch, Mein Leben Und Mein Wandern,(Berlin, 1894), p. 46.

${ }^{51}$ Janes Jankowski and Israel Gershoni(ed.), Rethinking Nationalism in the Arab Middle East, (Columbia University Press, 1997), p.131.

${ }^{52}$ Heinrich Brugsch, Mein Leben und Mein Wandern, p. 112.

${ }^{53}$ Elliott Colla, Conflicted Antiquities, Egyptology, Egyptomania, Egyptian Modernity, (Duke University Press, 2007), p.142.

${ }^{54}$ Heinrich Brugsch, mein Leben und mein Wandern, p. 242.

${ }^{55}$ Ibid.,p.243.

${ }^{56}$ Jean Marcel Humbert and Clifford Price (ed.), Imhotep Today. World Exhibitions Egyptianizing Architecture,(London, 2003) p.124.

${ }^{57}$ Mary Ann Gallagher, Mattew Garner, and Sdakat Kadri, Vienna Prague Budapest, (London, 2007) p.263.

${ }^{58}$ Bruno Giberti, Designing the Centennial. A History of the 1876 International Exhibition in Philadelphia,

(Kentucky University Press, 2002) p. 91.

${ }^{59}$ Heinrich Brugsch, Mein Leben und Mein Wandern, p. 277

${ }^{60}$ Ibid.,p.280.

${ }^{61}$ The Proceedings of the Second International Congress of Orientalists, (London, 1874) p.42.

${ }^{62}$ Johannes Dumichen, Der Agyptishe Falsetempel Von Abu Simbel und seine Bildwerke und Inschriften, (Leipzig, 1869), p.III.

${ }^{63}$ George Washington Moon, Men and Women of the Time. A Dictionary of Contemporaries, ( Routledge, London, 1891), p. 284.

${ }^{64}$ Adolf Erman, Agyptologie als Wissenschaft 1854-1937, in seiner Zeit, (Berlin,2006).

${ }^{65}$ Edward A Park and Samuel Taylor(ed.), Bibliotheca Sacra, vol XXVII, ( Warren F.Draper,London,1870), p. 180 .

${ }^{66} \mathrm{He}$ published the photos of the monuments in his book, Dumichen, Resultate der Auf Befehl Sr. Majestat des Konigs Wilhelm I von Preussen in Sommer 1868 nach Agypten Entsendeten expedition, Berlin, 1869)(

${ }^{67}$ Margaret Drower, Flinders Petrie. A Life in Archeology, the University of Wisconsin Press, London, 1995, p. 36 .

${ }^{68}$ Katherine Blouin, Triangular Landscapes Environment, Society, and the State in the Nile Delta under Roman Rule, Oxford University Press, 2014 p.40.

${ }^{69}$ Casten Reinhard and Anthony S.Travis, Heinrich Caro and the Creation of the Modern Chemical Industry, (Kluwer Academic Publishers, Netherlands, 2000), p. 368.

${ }^{70}$ August Eisenlohr, Aus einen Briefe des Prof Eisenlohr, Zietschrift fur Agyptische Sprache und de Altertumskunde, DreiundWanzigste,1880, p. 55.

${ }^{71} 56$. Ibid., p.

${ }^{72}$ The Great Harris Papyrus resides in a British museum. It is a huge role, 130 feet long, containing 117 columns about one foot high and was found in a tomb near Madient Habu in Thebes. It is the longest papyrus to have come from Egypt. For more on the papyrus, see August Eisenlohr, Der Grosse Papyrus Harris, (Leipzig, 1972).

${ }^{73}$ Marshall Clagett, Ancient Egyptian Science,A Source Book, Vol.III. Ancient Egyptian Mathematics, (Philadelphia, 1999) p.114.

${ }^{74}$ James Newman(ed.), The World of Mathematics, Vol I, (Simon and Schuster Press, New York,1956), p. 170.

${ }^{75}$ Cambridge University Press, 2002), p.218.(Amalia Edwards, Pharaohs, Fellahs and Explorers

${ }^{76}$ George Ebers, The Story of My Life, $\mathrm{h}$ ttps://archive.org/stream/thestoryofmylife05599gut/old/g160v10.txt

${ }^{77}$ Cyril P. Bryan, The Papyrus Ebers, (London, 1930), p.xiii.

${ }^{78}$ Ibid., p.iv.

${ }^{79}$ Bruno Haliova and Bernard Ziskind, Medicine in the Days of the Pharaohs, (Harvard University Press, 2005) p.102. 


\section{البعثات الأثرية الألمانية في مصر خلال عصر الخديوي إسماعيل 1863-1879}

\section{ايناس فارس يحيى}

كلية السياحة و الفنادق - جامعة المنيا

على الرغم من أن علم المصريات لم يلق اهتمام الحكام المصريين في عصر أسرة محمد علي، إلا أن الخديوي إسماعيل قد أولي له الكئل الكثير من

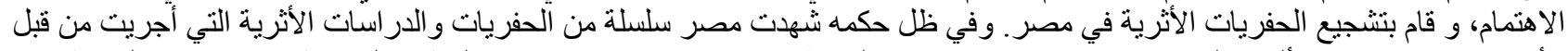

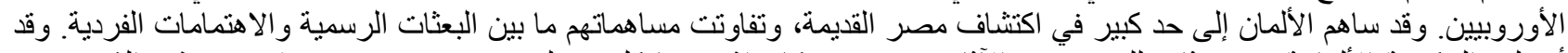

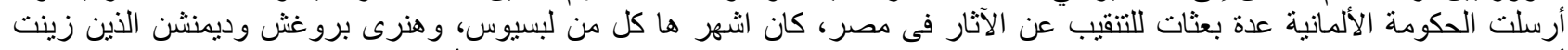

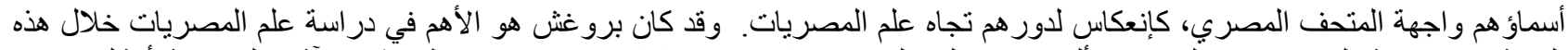

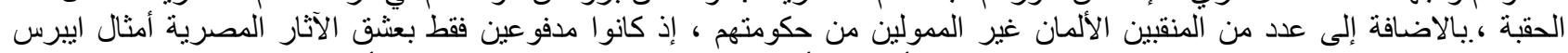

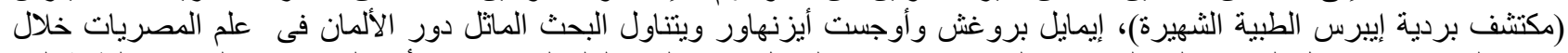

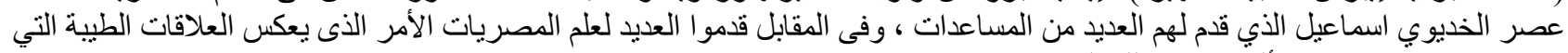

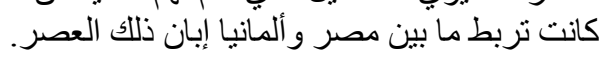

